\title{
THE IMPACT OF ISLAMIC FINANCIAL DEVELOPMENT ON ENERGY INTENSITY: EVIDENCE FROM ISLAMIC BANKS
}

\author{
Abdul-Jalil Ibrahim ${ }^{1 *}$, Nasim S. Shirazi ${ }^{2}$ and Amin Mohseni-Cheraghlou ${ }^{3}$ \\ ${ }^{1 *}$ Corresponding author. Islamic Finance Department, Hamad Bin Khalifa University, Doha, Qatar, \\ abdibrahim@hbku.edu.qa \\ ${ }^{2}$ Islamic Finance Department, Hamad Bin Khalifa University, Doha, Qatar \\ ${ }^{3}$ Department of Economics, American University, Washington D.C, United States
}

\begin{abstract}
The relationship between financial development and energy intensity is yet to be firmly established as the literature develops, and the few empirical studies conducted provide conflicting results. While some conclude that there is a U-shaped relationship between financial development and energy intensity, others show a linear relationship between the two variables. This study investigates the relationship between financial development and energy intensity by focusing on the role of Islamic financial development. It covers 30 countries where Islamic banks are present. Using the fixedeffects panel model, the empirical results suggest that Islamic banking development significantly increases energy intensity in the sample countries. We also identify other important factors that increase it. These include carbon emissions, renewable energy use and energy imports. The findings point to the importance of designing policies to incentivise Islamic banks and Shari'ah-compliant investors to finance clean energy technologies as a potent tool for reducing energy intensity, achieving sustainable development, and greening Islamic finance.
\end{abstract}

Keywords: Islamic financial development, Renewable energy, Islamic banks, Energy intensity, Sustainability.

JEL classification: G18; G21; G28.

Article history:

Received : August 22, 2021

Revised : November 18, 2021

Accepted : November 25, 2021

Available online : November 30, 2021

https://doi.org/10.21098/jimf.v7i4.1409 


\section{INTRODUCTION}

The United Nations' SDG 7 aspires to "ensure access to affordable, reliable, sustainable and modern energy for all"(UN, 2021). Energy plays a vital role in achieving the 2030 Agenda for Sustainable Development set by the United Nations. Achieving the related goals will contribute to the mitigation of climate change (IEA, IRENA, UNSD, World Bank, \& WHO, 2020). The Conference of the Parties 21 (COP 21) in Paris on November 30 to December 12, 2015 saw countries commit to a climate change agreement to keep the global rise in temperature to less than 2 degrees Celsius. There are opportunities to invest in climate-related projects valued at US\$23 trillion in emerging markets in the period 2016- 2030, based on IFC analysis (IFC, 2020).

Sustainable development requires energy to be used efficiently; one of the measures of such efficiency is energy intensity (Wang, Zhao, \& Li, 2019). Globally, primary energy intensity has seen a decreasing trend for the past decade, falling from 5.9 MJ/USD in 2010 to $5.0 \mathrm{MJ} / \mathrm{USD}$ in 2017. However, the annual improvement slowed to $1.7 \%$ in 2017 , missing the SDG7.3 energy intensity improvement target of a $2.6 \%$ reduction. According to IEA et al. (2020), this was due to poor energy efficiency policies in many developed and emerging economies.

In the Middle East and North Africa, where Islamic finance has a significant penetration, energy intensity has not only trailed behind other regions (Sinton \& Dave, 2016) but has also recorded no improvement over the years. For instance, while there was a yearly decrease of 2.5 percent in energy intensity among lowermiddle-income countries globally between 2000 and 2012, the energy intensity of MENA countries of the same income group increased by 0.4 percent. A similar observation can also be made for MENA and non-MENA countries in the uppermiddle-income and high-income groups. Figure 1 shows that energy intensity in the world decreased from $142 \mathrm{~kg}$ of oil equivalent/\$ 2017 PPP GDP in 2001 to $124 \mathrm{~kg}$ of oil equivalent/\$ 2017 PPP GDP in 2013. However, in the MENA region energy use increased from $129 \mathrm{~kg}$ of oil equivalent/\$ 2017 PPP GDP in 2001 to 141 $\mathrm{kg}$ of oil equivalent $/ \$ 2017$ PPP GDP in 2013. This development could potentially affect the achievement of SDG 7 in the MENA region and the world at large.

In the literature, the IPAT model (influence, population, affluence, and technology) of Ehrlich \& Holdren (1971) and the STIRPAT model of Dietz \& Rosa (1997) provide theoretical foundations for understanding energy intensity determinants. Empirically, energy intensity rises over the years have been attributed to international trade, technology, economic growth, and structural effects (Nie \& Kemp, 2013; Wang et al., 2019). Other factors that may influence such a trend include population density, urbanisation, lifestyle, and renewable energy use (Rafiq, Salim, \& Nielsen, 2016). Furthermore, Sequeira \& Santos (2018) show that educational level influences energy intensity positively after controlling for per capita income, industrialisation, and energy structure. 


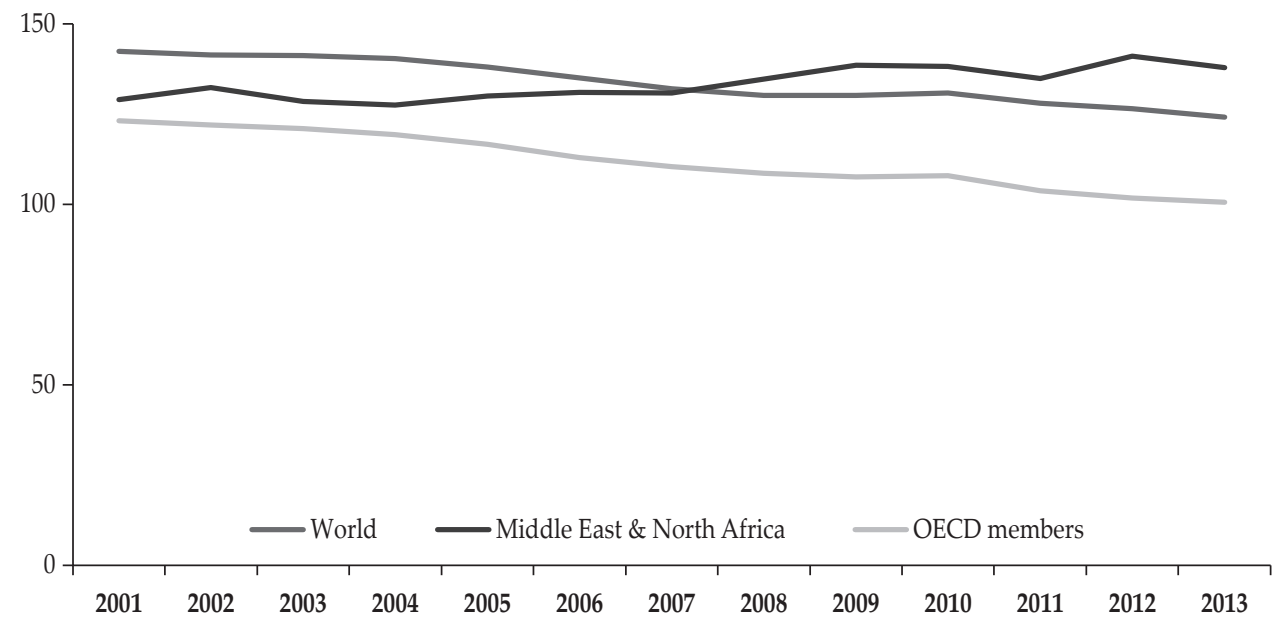

Source: WDI (2020)

Figure 1.

Energy Use Comparison

Levine \& Zervos (1998), Xu (2000), and Fung (2009) argue that financial development positively influences improvements in growth, capital accumulation, and productivity in an economy. Financial development stimulates many changes within a country, including more transparent lender-borrower relationships, financial risk mitigation, access to more financial capital, a reduction in borrowing costs, and access to energy-efficient products and the latest technology. There will be increased energy consumption and uptake in business investment through these channels (Sadorsky, 2011). Financial development therefore potentially influences the attainment of ideal energy intensity in a country (Acheampong, 2019) and can affect energy intensity through direct, business, and wealth channels (Sadorsky, 2010, 2011; Shahbaz \& Lean, 2012). Through the direct channel, individuals can acquire consumer goods such as fridges and air conditioners when funds are available in a developed financial system, which influences energy intensity (Tamazian, Chousa, \& Vadlamannati, 2009). Through the business channel, the financial system can allocate funding for R\&D on advanced technologies, as mature financial systems better understand risks and are better able to manage them (Tamazian et al., 2009). The funding of new technologies will lead to energy efficiency gains, affecting energy use per output. In addition, the wealth channel provides an opportunity for the stock market to create capital for businesses to grow and to stimulate investment, thus funding innovative projects and helping enterprises to gain economies of scale, which may influence energy intensity (Sadorsky, 2010).

Chen, Huang, \& Zheng (2019) were perhaps the first to study the impact of financial development on energy intensity, based on a global sample. They investigated 98 countries over the period 1990-2014 using a two-way fixed-effect 
model. Their findings show that a developed financial sector can reduce the intensity of energy in non-OECD countries, but has no impact on OECD countries. Their study also reports a nonlinear relationship between energy intensity and financial development in non-OECD countries. These findings agree with the contention of the role of technology in reducing energy intensity espoused by Sun (2002) and Ward, Radebach, Vierhaus, Fügenschuh, \& Steckel (2017). A more recent study by Canh, Thanh, \& Nasir (2020), using a global sample of 81 countries spanning the period 1997-2013, concludes that a developed financial sector directly influences production energy intensity. In the long run, a developed financial institution increases consumption energy intensity, while capital markets reduce it. Their study further concludes that production energy intensity falls in advanced countries in line with increasing financial development, confirming the work of Chen et al. (2019). Pan, Uddin, Han, \& Pan (2019) conclude that in the case of Bangladesh, financial development exerts causality on energy intensity, but the impact slows down in the long run compared to that of technology, whose impacts on energy intensity increase in the long run.

The financial development-energy intensity nexus is yet to be firmly established as the literature is still emerging, but the few empirical studies conducted have obtained conflicting results. Whereas Chen et al. (2019) conclude that there is a U-shaped link between energy intensity and financial development, the findings of Canh et al. (2020), Hussain et al. (2020), and Pan et al. (2019) show a direct relationship between the two. The demand for energy in an economy can be complicated, and the manifestation of the determinants of energy intensity needs further studies, especially on the role of financial development. Accordingly, this study aims to determine the impact of Islamic financial development on energy intensity and to contribute to the general understanding of the relationship in the literature.

The study contributes in two ways. First, it provides further evidence on the financial development-energy intensity nexus. Second, it focuses on the impacts of Islamic finance development on energy intensity. While Islamic finance has witnessed rapid growth, its relation to energy intensity remains a gap in the literature. Various countries with different levels of economic development have been studied, including Gaies, Kaabia, Ayadi, Guesmi, \& Abid (2019) research on the MENA region. However, to the best of our knowledge, no studies have been conducted that consider the role of Islamic financial development. Over the years, such development grew to an estimated USD 2.44 trillion in 2019 (IFSB, 2020), with the Islamic banking sub-sector accounting for $72.4 \%$ of total outstanding assets. In some jurisdictions, such as Saudi Arabia, the IFSB (2020) reports close to 70\% Islamic banking penetration. The relationship between financial development and energy use, and given the fact that Islamic banks are involved in equity financing but do not invest in or finance speculative assets, has ignited an empirical inquiry. The importance of the differentiation between Islamic banks and conventional banks can be seen in the findings of Beck, Demirguc-Kunt, \& Merrouche (2013) and Hardianto \& Wulandari (2016), who show that there is more financial intermediation among Islamic banks and higher non-interest income. Finally, the greening of the financial system requires an inclusive approach. The significant penetration of Islamic banking in some Islamic countries also needs to be integrated 
through such an approach. Therefore, it is essential to investigate the relationship between Islamic banking development and its economic contribution, considering its nature and the nuances of the impact of Islamic financial development on energy policy (Mensi, Hammoudeh, Tiwari, \& Al-Yahyaee, 2020).

The remainder of the paper is structured as follows. The literature review is presented in section two, while section three details the research methodology, regression model, and data sources. Section four presents the major findings and discussion of these. The paper ends with the concluding section and recommendations.

\section{LITERATURE REVIEW}

\subsection{Real Economy, Financial Development, and Energy Intensity}

Theoretically and empirically, it has been widely concluded that financial development plays a vital role in economic development (Schumpeter, 1934; King \& Levine, 1993; Levine \& Zervos, 1998; Frankel \& Romer, 1999; Wu, Hou, \& Cheng, 2010; Durusu-Ciftci, Ispir, \& Yetkiner, 2017; Mahi, Phoong, Ismail, \& Isa, 2020). Financial institutions pool funds from surplus economic units and channel them to innovative entrepreneurs and economic units in deficit for productive uses (King \& Levine 1993). Many studies have conducted empirical investigations and confirmed robust relations between economic growth and financial development (King \& Levine 1993). As one of the pioneering studies in the 1990s, King and Levine's (1993) model links economic growth, finance and entrepreneurship by building on the work of Frank Knight (1951) and Joseph Schumpeter (1912). They conclude that a developed financial sector leads to successful innovation and growth in the economy.

Two views exist on the finance-growth connection. Whereas Goldsmith (1969) and Shaw (1973) posit the leading role of finance in economic activity, Robinson (1952) argues that real economic growth leads, while finance follows. These contrasting views have motivated a plethora of studies, with the majority of evidence pointing towards the positive roles of finance in economic development, although some have cautioned that finance can impede growth and that there could be moderating factors in the finance - growth relationship. Zabavnik \& Verbič (2021) conducted a meta-analysis of the finance - growth literature.

Economic growth cannot occur without the use of energy resources, which is espoused by a notion which constitute the growth-energy nexus (Squalli, 2007; Yu \& Choi, 1985; Nasreen \& Anwar, 2014; Shahbaz, Hye, Tiwari, \& Leitão, 2013; Furuoka, 2016; Sarwar, Chen, \& Waheed, 2017). Businesses and households finance energy resources and technologies through the financial system. The level of energy consumption can be influenced by the financing available, which has motivated a wave of research on the finance-energy nexus, including works by Zhang (2011), Sadorsky (2011), Tamazian \& Rao (2010), and Gaies et al. (2019). However, the empirical evidence of the relationship between financial development and energy consumption is inconclusive. One strand of the literature contends that financial development leads to higher energy consumption (Tamazian \& Rao, 2010; Sadorsky, 2011), whiles another argues that they have an inverse relationship (Tamazian et al., 2009; Hübler \& Keller, 2010). 
In the wake of the impacts of climate change and mitigation strategies, a branch of research also considers financial development and energy efficiency, measured through energy intensity. Energy intensity (or energy output ratios) is the ratio of primary energy supply to GDP (Bhattacharyya, 2019). When energy intensity decreases, this means that an economy is efficient in using energy to generate a particular level of GDP, and vice versa. In assessing the levels of energy efficiency in economies, energy intensity is a better means of comparison than the energy consumption level (Pan et al., 2019).

Technology, economic growth, trade, and structural effects are factors that have been identified to have contributed to the fall in energy intensity in the last decade of the 20th century (Ward et al., 2017; Voigt, De Cian, Schymura, \& Verdolini, 2014; Taylor, d'Ortigue, Francoeur, \& Trudeau, 2010; Medlock \& Soligo, 2001; Waugh, 2010; Galli, 1998). However, additional factors, such as population density, urbanisation, educational level, lifestyle, and renewable energy use, have also been cited as determinants of energy intensity (Sequeira \& Santos, 2018, Rafiq et al., 2016).

Technological advancement is an essential determinant of energy intensity, as technology can lead to less energy use in achieving a particular output (Ward et al., 2017). For instance, the decline in OECD energy intensity over the period 19711998 has been attributed mainly to technological progress (Sun, 2002). Similar results have been observed in China, where energy intensity fell by over one-fifth between 2003 and 2010 (Du \& Lin, 2015).

Theoretically, three reasons explain why technological progress reduces energy intensity (Chen et al., 2019): efficiency improvements, a positive shift in energy structure, and economic development. On the contrary, a small number of researchers have argued that technology may lead to a reduction in energy efficiency due to the rebound effect. More energy will be consumed when energy costs fall due to improved technology, leading to high energy intensity, as claimed by Gillingham, Rapson, \& Wagner (2016). Furthermore, when there is a shift in economic output between energy-intensive and more minor energy-consuming sectors, energy intensity will be impacted. A case in point is when an economy shifts away from the manufacturing (high energy consumption) sector to a less energy-intensive sector, such as the light industrial sector with high technology or services. As a result, energy intensity will decline (Mulder, 2015). As of 2005, structural changes accounted for over $60 \%$ of the fall in energy intensity (Taylor et al., 2010).

Studies show that the energy intensity in production and consumption can show different patterns of behaviour during different economic stages. Some researchers report an inverted U-shape relationship between energy intensity and economic growth (Galli, 1998; Medlock \& Soligo, 2001). Such a relationship means that energy intensity increases during industrialisation due to the building of infrastructure and high energy-consuming industrial sectors. When economic growth subsequently rises, technological adaptation and energy efficiency gains occur, reducing energy intensity. Lescaroux (2011) reports a negative relationship between energy intensity and economic growth, which means that growth in an economy reduces energy intensity, especially in developed countries, where technological innovation drives growth. 


\subsection{Islamic Finance and Economic Growth}

Islamic finance differs from the conventional version in that it avoids interest, is linked directly to the real sector, and channels funds on the basis of risk-sharing and sales- and lease-based contracts (Iqbal \& Mirakhor, 2011; Beck, DemirgüçKunt, \& Merrouche, 2010). Islamic finance also forbids the trading of risky financial products such as derivatives (Askari, Iqbal, \& Mirakhor, 2011). These fundamental principles of Islamic finance notwithstanding, some still view it to be far from ideal. For instance, Chong \& Liu (2009) argue that, although equity-based Islamic financing as one of its distinct features, only a small proportion of Islamic bank financing is in fact based on this. Azmat, Skully, \& Brown (2015) also criticises Islamic finance practice for ignoring equity financing, revealing that debt contracts dominate Islamic banks' financial asset mix.

Although profit and loss sharing financing principles remain a challenge in current financial intermediation practice, equity financing has gained in prominence in some countries. Meslier, Risfandy, \& Tarazi (2020) and Abedifar, Molyneux, \& Tarazi (2013) show that $30 \%$ of total financing by Islamic banks in Indonesia is equity-based. In addition, El-Hawary, Grais, \& Iqbal (2007) document that the profit and loss sharing modes of financing range between 28 and 38 percent in Sudan. In an earlier work, Khan (1995) highlighted that equity financing represented $37 \%$ of Iranian Islamic bank assets.

The positive contribution of Islamic finance to economic development has been well documented in the literature (Grassa \& Gazdar, 2014; Imam \& Kpodar, 2016; Kassim, 2016; Tabash \& Dhankar, 2014; Caporale \& Helmi, 2018; Boukhatem \& Moussa, 2018). Beck et al. (2013) show that Islamic banks have higher asset quality, higher intermediation ratios and are well capitalised, findings that were later confirmed by Abedifar et al. (2013). Islamic banks are also more stable than conventional ones (Yousefi, Abizadeh, \& McCormick, 1997; Mobarek \& Kalonov, 2014). Whereas, Sorwar, Pappas, Pereira, \& Nurullah (2016) studied 65 Islamic and 65 conventional banks and found no difference in risk between them.

The welfare function of Islamic banks was also analysed by Gheeraert (2014) and confirmed by Abedifar et al. (2013), especially for low-income countries with a Muslim majority. Furthermore, Islamic banks contribute more to SME financing than conventional ones (Kumru \& Sarntisart, 2016).

The connection between the real economy and banks becomes apparent during periods of financial turmoil (Bernanke, 2018). In these times, Islamic markets perform better than conventional ones, as was evident during the 2007 global financial crisis (Rizvi, Arshad, \& Alam, 2015; Kenourgios, Naifar, \& Dimitriou, 2016). Similarly, Bilgin, Danisman, Demir, \& Tarazi (2021) investigated a sample of 416 banks, including 14\% Islamic banks and $86 \%$ conventional ones, in 12 countries. They concluded that Islamic bank credit is not affected negatively during economic uncertainty, unlike that of traditional banks. The asset-based and risk-sharing modes of financing of Islamic banks play a mitigating role in times of global financial turmoil (Hasan \& Dridi, 2011). In periods of domestic crisis, credit creation is constrained, but in Islamic banks the loan-deposit ratio is maintained (Beck et al., 2013).

The convergence of Islamic and conventional finance has been discussed in the literature (Haniffa \& Hudaib, 2010; Izzeldin, Johnes, Ongena, Pappas, \& Tsionas, 
2021). Despite this convergence movement, Sukmana \& Ibrahim (2017) found that Islamic banks' investment rates did not move linearly with conventional rates. Šeho, Bacha, \& Smolo (2020) also found that sale- and lease-based Islamic financing modes were negatively linked with interest rates, especially in developed Islamic banking markets. However, risk-sharing financing assets have a positive impact on interest rates.

The literature on financial development and energy consumption behaviour is not conclusive. Similar to the financial development-energy consumption nexus, findings on the finance-energy intensity nexus are inconclusive, as shown by a recent study by Acheampong (2019). Whereas some findings show a negative relationship between financial sector development and energy intensity, other evidence indicates a positive relationship. This creates a research gap in understanding the phenomenon, especially for countries where Islamic finance is growing qucikly. In terms of methodology and sampling, various countries with different levels of economic development have been studied, including the work of Gaies et al. (2019) on the MENA region. The gap identified within the research design context is that no study has considered Islamic financial development and energy efficiency or intensity. Over the years, such development has evolved, and in some jurisdictions, such as Saudi Arabia, there is close to $70 \%$ Islamic banking penetration (IFSB, 2020). Therefore, there is a need to consider the relationship between financial development and energy use, given that Islamic banks are involved in equity financing and do not invest in or hold financially speculative assets.

\section{MODELS, VARIABLES, AND DATA SPECIFICATION}

\subsection{Regression Model}

The study seeks to investigate the empirical relationship between Islamic financial development and energy intensity. To do this, 30 countries where Islamic finance is present were sampled. In the analysis, we adopted the energy demand function used by Hsing (1994) and Liu (2004), with financial development added as a potential driver in explaining energy intensity. Following Canh et al (2020), Chen et al. (2019), Gaies et al. (2019), Al-mulali et al. (2013), and Sadorsky (2011), we express the empirical model as follows:

$$
\begin{aligned}
& E I=\beta_{0}+\beta_{1} \text { IsAssets }_{i t}+\beta_{2} \text { Gdp }_{i t}+\beta_{3} \text { Gdpcapita }_{i t}+\beta_{4} \text { Service }_{i t}+
\end{aligned}
$$

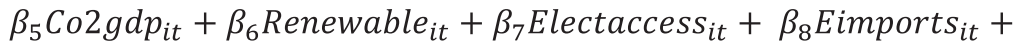

$$
\begin{aligned}
& \beta_{9} \text { Fossilfuel }_{i t}+\beta_{10} \text { Credit_banks }_{i t}+\lambda_{t}+v_{t i}+\varepsilon_{i t}
\end{aligned}
$$

where EI= energy intensity; lsAssets= credit by Islamic banks, total Islamic banking assets; Gdp=gross domestic product; Gdpcapita= GDP per capita; Service=service sector of the economy; $\mathrm{CO} 2 \mathrm{gdp}=\mathrm{CO} 2$ emissions; Renewable=renewable energy consumption; Electaccess=electricity access; Eimports=energy imports; Fossilfuel= fossil fuel consumption; Credit_banks= credit to the private sector by banks; and $\varepsilon^{\varepsilon}$ a random disturbance term. 
Energy intensity is expressed as energy use per \$1000 GDP (constant 2011 PPP). A low ratio indicates high energy efficiency. The explanatory variable of primary interest is the Islamic financial development indicator. Such development is proxied by total Islamic deposit money bank assets (i.e. IsAssets), in line with Sadorsky (2011). The expectation is that Islamic financial development will increase energy intensity due to the real-economic link of Islamic financial intermediation.

In our model specification, we control for certain variables, guided by previous studies. More specifically, the energy intensity factors are based on Dietz \& Rosa (1997) and Nie \& Kemp (2009), who specify the energy intensity function should include income, industrialisation and urbanisation as explanatory variables. These drivers have been used in several previous empirical studies, including recently by Pham, Huynh, \& Nasir (2020). We also control for the economic structure of the country, as represented by the output share of the service sector. Service increase is an indication of improving energy efficiency in the economy.

The literature concludes that energy intensity declines with income growth (Bernardini \& Galli, 1993; Sadorsky, 2013). Consequently, GDP and GDP per capita are included to control for the size of the economy and the wealth of citizens, respectively. However, $\mathrm{CO} 2$ emissions may increase with increasing energy intensity, especially when non-renewable sources of energy are consumed. Wang, Mirza, Vasbieva, Abbas, \& Xiong (2020) and Acheampong's (2019) findings reveal a positive relationship between carbon emissions and gross domestic product.

There is a negative relationship between economic growth and renewable energy consumption (Khan, Chenggang, Hussain, \& Kui, 2021). Chen et al. (2020) also show that higher renewable energy consumption in developing countries may positively impact economic growth, but that below a certain threshold this will negatively affect economic growth.

Energy imports (Eimports) are likely to lead to increased energy consumption, which informed the need for the model to control for energy imports. Conventionally, energy security concerns have seen energy importing countries more aligned towards non-fossil fuels (Asafu-Adjaye, Byrne, \& Alvarez, 2016). In addition, many developing economies usually have fewer energy intensive industries, which may reduce energy intensity. Electricity access (Electaccess) in an economy may lead to higher energy intensity, especially when households do not use energy-efficient appliances (Ozturk, 2010). According to Hanif (2018), fossil fuel (Fossilfuel) consumption positively correlates with energy intensity and carbon emissions, especially in developing countries. Financial development (Credit_banks) has a positive relationship with energy consumption (Gaies et al., 2019) and a negative connection with energy intensity in non-OECD countries (Chen et al., 2019). Table 1 gives the descriptions and sources of the key variables used in the study.

We estimated the model using the fixed-effects panel estimator. With the fixedeffect model, country-specific and time-specific invariant factors can be correlated with independent variables, e.g. Islamic finance assets. Therefore, for panel data, the fixed-effects panel is used to minimise bias due to omitted variables that do not change over time or change in equal measure for all countries (Studenmund, 2014) 
Table 1.

Description of the Variables

\begin{tabular}{|c|c|c|c|c|}
\hline Symbol & Variable & Definition & Unit & Data Source \\
\hline$E I$ & Energy intensity & $\begin{array}{l}\text { Energy use (kg of oil } \\
\text { equivalent) per \$1,000 GDP } \\
\text { (constant 2017 PPP) }\end{array}$ & $\begin{array}{c}\mathrm{kg} \text { of oil } \\
\text { equivalent } / \$ \\
2017 \text { PPP GDP }\end{array}$ & WDI \\
\hline Is Assets & $\begin{array}{c}\text { Islamic financial } \\
\text { development }\end{array}$ & $\begin{array}{l}\text { Islamic banking assets as a } \\
\text { proportion of GDP }\end{array}$ & $\%$ & Bankscope \\
\hline$G d p$ & GDP & GDP (2010 constant USD) & US\$ & WDI \\
\hline Gdpcapita & GDP per capita & $\begin{array}{l}\text { GDP per capita (constant } \\
2010 \text { US\$) }\end{array}$ & $\%$ & WDI \\
\hline Services & Services & $\begin{array}{l}\text { Services, value added (\% } \\
\text { of GDP) }\end{array}$ & $\%$ & WDI \\
\hline Co2gdp & CO2 emissions & $\begin{array}{l}\text { CO2 emissions (kg per } \\
2010 \text { US\$ of GDP) }\end{array}$ & $\%$ & WDI \\
\hline Renewable & Energy structure & $\begin{array}{c}\text { Renewable energy } \\
\text { consumption (\% of total } \\
\text { final energy consumption) }\end{array}$ & $\%$ & WDI \\
\hline Electaccess & Electricity access & $\begin{array}{l}\text { Access to electricity (\% of } \\
\text { the population) }\end{array}$ & $\%$ & WDI \\
\hline Eimports & Energy imports & $\begin{array}{l}\text { Energy imports, net (\% of } \\
\text { energy use) }\end{array}$ & $\%$ & WDI \\
\hline Fossilfuel & Energy structure & $\begin{array}{l}\text { Fossil fuel energy } \\
\text { consumption (\% of total) }\end{array}$ & $\%$ & WDI \\
\hline Credit_banks & $\begin{array}{c}\text { Financial } \\
\text { development }\end{array}$ & $\begin{array}{l}\text { Domestic credit to the } \\
\text { private sector by banks (\% } \\
\text { of GDP) }\end{array}$ & $\%$ & WDI \\
\hline
\end{tabular}

\subsection{Data}

Bankscope and the World Development Indicators (WDI) database of the World Bank were the sources of the data used in the analysis. Deposit Money Bank Assets data were sourced from Bankscope, while energy intensity, GDP, service sector, $\mathrm{CO} 2$ emissions, renewable energy consumption, fossil fuel consumption, and credit to the private sector by deposit-taking banks data were sourced from the WDI database.

The countries selected for the study were Saudi Arabia, Iran, Indonesia, Malaysia, United Arab Emirates, Turkey, Kuwait, Qatar, Bangladesh, Pakistan, Indonesia, Sudan, Bahrain, Jordan, Egypt, the United Kingdom, Brunei Darussalam, Lebanon, the Cayman Islands, Gambia, Iraq, Singapore, Jordan, the Maldives, Mauritania, Russia, Syria, Bahrain, Tunisia, West Bank Oman, Gaza and Yemen. According to IFSB (2020), Islamic finance in these countries constitutes almost $100 \%$ of global Islamic assets.

Table 2 gives descriptive statistics of the variables and their pairwise correlations. The correlation matrix helps to establish the degree of association between the variables used in the analysis and to identify correlations between them. The results show that Islamic financial development, GDP per capita, carbon emissions, electricity access, and fossil fuel are positively correlated with energy intensity. On the other hand, bank services, renewable energy, energy imports, and credit to the private sector have an inverse relationship with energy intensity. 
Table 2.

Descriptive Statistics and Correlation of the Key Variables

\begin{tabular}{|c|c|c|c|c|c|c|c|c|c|c|c|}
\hline Variable & EI & IsAssets & Gdp & Gdpcapita & Services & Co2gdp & Renewable & Elect & Eimports & Fossilfuel & $\begin{array}{l}\text { Cred } \\
\text { bank }\end{array}$ \\
\hline Obs & 259 & 317 & 306 & 306 & 277 & 306 & 317 & 301 & 280 & 251 & 300 \\
\hline Mean & 130.846 & 21.562 & 260.028 & 15.944 & 48.107 & 0.68 & 13.024 & 88.054 & -134.382 & 86.899 & 44.59 \\
\hline Std. Dev. & 53.977 & 26.129 & 458.652 & 19.201 & 11.691 & 0.319 & 19.924 & 22.259 & 204.245 & 21.139 & 33.666 \\
\hline Min & 31.568 & 0.005 & 1.04 & 0.781 & 25.251 & 0.097 & 0 & 18.2 & -849.555 & 0 & 1.552 \\
\hline Max & 312.674 & 100 & 2605.106 & 69.679 & 77.694 & 1.77 & 80.848 & 100 & 98.247 & 100 & 192.123 \\
\hline EI & 1 & & & & & & & & & & \\
\hline IsAssets & $0.330^{*}$ & 1 & & & & & & & & & \\
\hline Gdp & $-0.125^{*}$ & $-0.176^{*}$ & 1 & & & & & & & & \\
\hline Gdpcapita & $0.175^{*}$ & -0.02 & $0.162^{*}$ & 1 & & & & & & & \\
\hline Services & $-0.310^{*}$ & $-0.396^{*}$ & $0.275^{*}$ & -0.005 & 1 & & & & & & \\
\hline Co2gdp & $0.662^{*}$ & $0.162^{*}$ & -0.098 & $-0.117^{*}$ & $-0.132^{*}$ & 1 & & & & & \\
\hline Renewable & $-0.195^{*}$ & -0.093 & -0.093 & $-0.468^{*}$ & -0.106 & $-0.412^{*}$ & 1 & & & & \\
\hline Elect & 0.115 & -0.076 & $0.217^{*}$ & $0.414^{*}$ & $0.293^{*}$ & $0.350^{*}$ & $-0.752^{*}$ & 1 & & & \\
\hline Eimports & $-0.259^{*}$ & $-0.351^{*}$ & $0.215^{*}$ & $-0.586^{*}$ & $0.699^{*}$ & 0.053 & $0.298^{*}$ & $-0.132^{*}$ & 1 & & \\
\hline Fossilfuel & $0.134^{*}$ & 0.062 & 0.024 & $0.365^{*}$ & 0.069 & $0.419^{*}$ & $-0.968^{*}$ & $0.772^{*}$ & $-0.260^{*}$ & 1 & \\
\hline Cred_bank & $-0.228^{*}$ & $-0.217^{*}$ & $0.544^{*}$ & $0.347^{*}$ & $0.563^{*}$ & -0.088 & $-0.389^{*}$ & $0.467^{*}$ & $0.261^{*}$ & $0.311^{*}$ & 1 \\
\hline
\end{tabular}

${ }^{*} \mathrm{p}<0.05$

\section{FINDINGS AND DISCUSSION}

This section presents the results of the panel fixed-effects regression model linking energy intensity to Islamic finance and other determinants. They are shown in Table 3.

In Model 1, pooled OLS is used. It is noted that IsAsset is significant at the 1\% level. Models 2-11 add other control variables and employ the fixed-effects panel model. IsAssets carries a positive and significant coefficient in 8 of the 11 regressions. Based on model 10, a 1\% increase in IsAssets will lead to a $0.114 \%$ increase in energy intensity. This provides strong evidence that a higher share of Islamic assets in the banking system is correlated with higher energy intensity. This result perhaps stems from the fact that Islamic finance has direct links to the real economy, hence making the economy more energy intensive. The results confirm the conclusions of Gaies et al (2019), Imam \& Kpodar (2016), Sadorsky (2011), Tamazian \& Rao (2010), and Zhang (2011). 
Table 3.

Regression Models

\begin{tabular}{|c|c|c|c|c|c|c|c|c|c|c|c|}
\hline & Model 1 & Model 2 & Model 3 & Model 4 & Model 5 & Model 6 & Model 7 & Model 8 & Model 9 & Model 10 & Model 11 \\
\hline $\begin{array}{l}\text { Dependent } \\
\text { variable }\end{array}$ & EI & EI & EI & EI & EI & EI & EI & EI & EI & EI & EI \\
\hline IsAssets & $0.648^{* * *}$ & 0.00148 & 0.0764 & 0.0629 & $0.207^{*}$ & $0.222^{* *}$ & $0.164^{* *}$ & $0.135^{* *}$ & $0.117^{* *}$ & $0.114^{* *}$ & $0.106^{* *}$ \\
\hline Gdp & & & $-0.0593^{*}$ & -0.0562 & $-0.0475^{*}$ & $-0.0413^{*}$ & 0.00186 & -0.00345 & -0.0148 & -0.01 & -0.0013 \\
\hline Gdpcapita & & & & $1.296^{* * *}$ & $0.635^{* * *}$ & $0.303^{* * *}$ & $-0.227^{*}$ & $-0.241^{* *}$ & -0.0427 & -0.132 & -0.0984 \\
\hline Services & & & & & $-1.349^{*}$ & -0.984 & 0.0198 & 0.037 & 0.2 & 0.0627 & 0.156 \\
\hline Co2gdp & & & & & & $72.00^{* * *}$ & $93.17^{* * *}$ & $99.08^{* * *}$ & $72.42^{* * *}$ & $83.11^{* * *}$ & $73.04^{* * *}$ \\
\hline Renewable & & & & & & & $3.538^{* * *}$ & $3.529^{* * *}$ & $3.286^{* * *}$ & $4.160^{* * *}$ & $4.033^{* * *}$ \\
\hline Electaccess & & & & & & & & -0.309 & -0.343 & -0.22 & $-0.422^{*}$ \\
\hline Eimports & & & & & & & & & $0.0757^{* * *}$ & $0.0707^{* * *}$ & $0.0770^{* * *}$ \\
\hline Fossilfuel & & & & & & & & & & $1.046^{*}$ & 0.952 \\
\hline Credit_banks & & & & & & & & & & & 0.0284 \\
\hline Constant & $117.1^{* * *}$ & $130 . .^{* * *}$ & $147.3^{* * *}$ & $170.6^{* * *}$ & $209.0^{* * *}$ & $133.2^{* *}$ & 5.718 & 31.5 & 60.57 & -62.76 & -37.64 \\
\hline Observations & 259 & 259 & 259 & 259 & 230 & 230 & 230 & 216 & 214 & 198 & 196 \\
\hline R-squared & 0.109 & 0 & 0.058 & 0.14 & 0.198 & 0.361 & 0.64 & 0.671 & 0.729 & 0.762 & 0.76 \\
\hline $\begin{array}{l}\text { Robust } \\
\text { standard } \\
\text { errors }\end{array}$ & YES & YES & YES & YES & YES & YES & YES & YES & YES & YES & YES \\
\hline $\begin{array}{l}\text { Type of } \\
\text { Regression }\end{array}$ & $\begin{array}{l}\text { Pooled } \\
\text { OLS }\end{array}$ & $\begin{array}{c}\text { Panel } \\
\text { OLS }\end{array}$ & $\begin{array}{l}\text { Panel } \\
\text { OLS }\end{array}$ & $\begin{array}{l}\text { Panel } \\
\text { OLS }\end{array}$ & $\begin{array}{l}\text { Panel } \\
\text { OLS }\end{array}$ & $\begin{array}{l}\text { Panel } \\
\text { OLS }\end{array}$ & $\begin{array}{l}\text { Panel } \\
\text { OLS }\end{array}$ & $\begin{array}{l}\text { Panel } \\
\text { OLS }\end{array}$ & $\begin{array}{l}\text { Panel } \\
\text { OLS }\end{array}$ & Panel OLS & Panel OLS \\
\hline Fixed Effect & NO & YES & YES & YES & YES & YES & YES & YES & YES & YES & YES \\
\hline
\end{tabular}

The estimated positive coefficient of gdpcapita in Models 4-6 is significant at the $1 \%$ level. This implies that a $1 \%$ increase in per capita GDP leads to a $0.303 \%$ increase in energy intensity in Model 6. Gdpcapita has an inverse relationship with energy intensity in Models 7-11 but is only significant at the levels of $10 \%$ and $5 \%$ for Models 7 and 8 . This means that economic growth may increase energy intensity at its initial stages. However, with the increasing wealth of countries and awareness of energy efficiency and technology improvements, the trend is one of decreasing energy intensity. This provides evidence that energy intensity drops as wealth increases (the inverted U theory), which confirms the findings of Galli (1998) and Medlock \& Soligo (2001), but contrasts with the results of Chen et al (2019), who finds a U-shaped relationship between the two variables in developing countries.

Co2gdp shows a positive coefficient and is highly significant for all six models at the $1 \%$ significance level. The estimates show that a $1 \%$ increase in Co2gdp is associated with an increase in $83.1 \%$ in energy intensity in the benchmark model. This indicates that most of the countries in the sample are energy-intensive, which comes at a cost to the environment and leads to high $\mathrm{CO} 2$ emissions. These findings on the strong correlation between $\mathrm{CO} 2$ emissions and energy intensity are not surprising and point to the fact that the energy used in the sample countries is mainly fossil-based. This confirms the findings of Namahoro, Wu, Zhou, \& Xue (2021); Sehrawat, Giri, \& Mohapatra (2015); and Liu \& Hao (2018). In addition, 
Hunjra, Tayachi, Chani, Verhoeven, \& Mehmood (2020) and Rjoub et al. (2021) recent findings show that financial development increases $\mathrm{CO} 2$ emissions and moderates the relationship between them and economic growth. Since financial development leads to increasing energy intensity, it should be noted that increasing financial development may also increase $\mathrm{CO} 2$ emissions, as most energy sources are non-renewable ones.

The renewable energy coefficient is positive and significant at the $1 \%$ level. This provides strong evidence of the correlation between renewables and energy intensity. Energy intensity increases by $4.16 \%$ when renewable energy consumption increases by $1 \%$. Increasing intensity comes with a higher cost of energy (direct and indirect environmental costs). Energy intensity through fossil fuel degrades the environment through high greenhouse gas emissions. In the case of renewable energy, environmental damage is mitigated. Almost all the countries under study are developing countries and thus require more energy to grow their economies. The findings corroborate the conclusions of Chen et al. (2019), that a lower proportion of renewable energy in the energy mix leads to economic growth and, by extension, increases energy intensity. These findings are not surprising, as most countries in the study have a low proportion of renewable energy use in their energy mix.

Energy imports have a positive coefficient and are highly significant at the $1 \%$ level. A $1 \%$ increase in energy imports leads to a $0.07 \%$ increase in energy intensity, which shows that more energy-intensive economies also tend to import more energy. This is as expected, as most of the countries in the sample are net energy importing ones. These findings contradict those of Asafu-Adjaye et al. (2016), who conclude that energy importers in developing countries usually have low energy intensity because of their less-energy intensive industries and their broader energy mix. The results of this may explain the fact that the energy supply sources in the sample countries are less diversified and rely heavily on fossil fuel imports to power economic growth.

The findings reveal that Islamic financial development leads to increased energy intensity. Since most countries in the sample rely on non-renewable energy sources to grow their economies, it is imperative to pursue clean energy sources to mitigate the impact of high energy intensity on carbon emissions. The increase in energy intensity leads to economic dependence on non-renewable energy consumption, increasing carbon emissions (Wang \& Wang, 2020). Cohen (2020) asserts that economic growth is not the cause of the climate crisis, but rather that it is the absence of public policy to pursue green growth. When energy intensity increases in an economy, it may not necessarily mean a negative development outcome, as it can also mean that energy is being used to generate economic growth. Mulder \& de Groot (2012) and Voigt et al. (2014) assert that declining energy intensity in advanced economies is due to energy efficiency, rather than an economic shift to cleaner energy use. Figure 2 shows that in many Islamic markets, the consumption of energy of transport, residences and the public sector is significant, and that renewable energy can play a significant role in mitigating the harmful effect of high energy intensity. Islamic financial institutions can finance targeted carbon-reducing technologies, such as positive screening of the financing of electric cars, solar photovoltaic system, and green building. 
Renewable energy uptake does not hamper economic growth, but rather, drives green growth. This is confirmed by the study of Middle Eastern and SouthEast Asian countries by Namahoro et al (2021), who conclude that renewable energy use is associated with economic growth. Despite the finding that renewable energy increases energy intensity in this our current study, a significant share of such energy use can reduce energy intensity. In their analysis of 82 countries, Yu et al. (2022) conclude that renewable energy reduces energy intensity, especially when usage is high in the energy mix. Similarly, Chakraborty \& Mazzanti (2020) demonstrate short- and long-term links between green energy innovation and energy intensity. Islamic finance can play a role in deploying the needed funding to foster renewable energy use. Its principles of fairness, equality, and ethics can promote and enhance sustainable development (SC \& World Bank, 2020). Maqasid al-Shariah essentialises these principles through the objectives of protecting property and progeny (Akram Laldin \& Furqani, 2013). Furthermore, the emergence of green finance allows Islamic finance to apply equity financing/ investment as a value proposition.

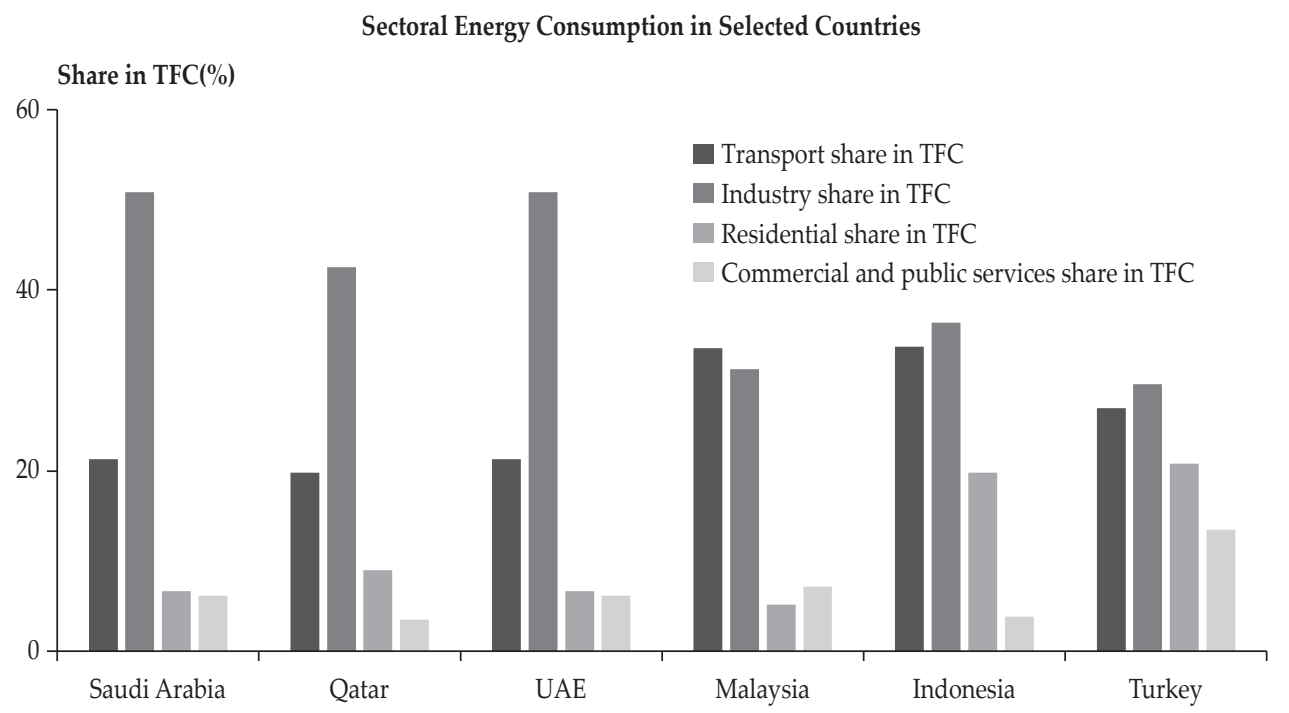

Source: IEA (2021)

Figure 2.

Energy Consumption of Selected Countries

Equity financing/investment dominated the financing mix of renewable energy in 2013-2016, with 35\% of financing instruments linked to this mode of financing. This provides evidence that Islamic financial institutions can deploy equity investments to accelerate clean energy technologies when they prioritise maqasid as a performance measure. This is more important given the fact that the weighted-average levelized cost of electricity (LCOE) from renewable energy sources fell between 2019 and 2020 by 13\% for onshore wind, 9\% for offshore 
wind, and 7\% for utility-scale solar photovoltaics (PV) (IRENA, 2021). Overall, 2010-2020 saw a decrease in the LCOE for utility-scale solar photovoltaics of $85 \%$, and $56 \%$ for onshore wind. This falling cost of renewable energy makes it more attractive for investment, but it cannot be left to market forces without appropriate policy to attract investments within the Islamic finance framework. Project-level financing and fiscal policies are two critical climate levers for fostering renewable energy investments and financing (Polzin, Egli, Steffen, \& Schmidt, 2019; World Bank, 2020). At the project financing level, musharakah and mudarabhah financing structures can be used to structure equity investments. This can be done through direct project structuring or green sukuk structures. In addition, blended finance provides an opportunity to create synergy between commercial and philanthropic capital. Within the Islamic finance framework, Khan \& Badjie (2020) propose a contract design that allows private capital to be deployed through its blending with philanthropic funds, with facilitation from the public sector. This blended finance structure allows Islamic financial institutions to provide capital to fund renewable energy projects. In contrast, charitable institutions such as waqf can bear the cost of finance, while fiscal policy can provide tax credit or the necessary regulatory or ecosystem support. A case in point is the solar investment tax credit (ITC) in the US, where a 26 percent federal tax credit can be claimed by a promoter or financier against the tax liability of residential (under Section 25D) and commercial and utility investors in solar energy (SEIA, 2021).

The MENA region accounts for a large proportion of Islamic finance assets and is one of the best-endowed regions of the world regarding solar energy potential. Al-Shalabi, Cottret, \& Menichetti (2014) report that the top five countries in terms of ideal solar energy potential for both photovoltaic (PV) and concentrating solar power (CSP) applications are Egypt, Oman, Saudi Arabia, Jordan, and the UAE. The availability of capital and a robust enabling environment for renewable energy in the Gulf Cooperating Countries has led to solar PV prices below 3 cents (USD 0.03) per kilowatt-hour and dispatchable concentrated solar power (CSP) of 7.3 cents per kilowatt-hour. These prices are lower than those of some natural gaspowered utilities in the region (IRENA, 2019). This provides a conducive economic atmosphere for renewable energy adoption.

Finally, fiscal and financial policy should create an opportunity to de-emphasise the interest rate shield by Islamic financial institutions to make renewable-energy equity financing attractive. Zaman, Hassan, Akhter, \& Brodmann (2019) contend that the interest shield contradicts the maqasid al Shariah and discourages equity financing. Therefore, fiscal policy should allow reframing of the tax shield in favour of equity financing through a tax credit in renewable energy investment/ financing.

\section{CONCLUSION AND RECOMMENDATIONS}

\subsection{Conclusion}

The role finance plays in economic growth has been well studied and recognised in the literature. Recent studies have shown how financial development affects energy intensity and environmental outcomes. This study covers 30 countries where Islamic banks are present covering the period 1999-2013 to understand the 
finance-energy intensity nexus in the context of Islamic finance. We used the fixedeffects model to study the relationship between Islamic financial development and energy intensity for Islamic finance markets. The results suggest that Islamic financial development, measured by deposit money bank assets, significantly increases energy intensity in the sample countries. In other words, Islamic financial development leads to inefficient use of energy. We have also identified important factors that increase energy intensity, including carbon emissions, renewable energy use, and energy imports.

\subsection{Recommendations}

The study findings imply that policymakers, such as central banks, need to design policies to incentivise Islamic banks to finance clean energy technologies as a potent tool for reducing energy intensity and achieving sustainable development in Islamic finance markets. In addition, Islamic green financing should be deployed to ensure that lower-cost finance is made available to renewable energy technologies, such as solar photovoltaic and wind energy projects.

In addition, energy conservation and environmental policies in jurisdictions with an Islamic finance presence should consider Islamic finance indicators in their energy demand function modelling, as concluded by Gaies et al. (2019). Innovative financing mechanisms should be encouraged to meet the targets for sustainable development in these countries (Jian, Fan, He, Xiong, \& Shen, 2019). Fiscal, market, and regulatory policies could be designed to attract renewable energy financing and investment by governments to encourage national, regional, and foreign investments in the renewable energy sector. The measures include tariffs, direct public investment, renewable energy subsidies, feed-in-premium, auctions for power purchase agreements, tax incentives, and subsidised investment funds (Polzin et al., 2019). These can contribute to the transfer and diffusion of clean energy technology in countries with an Islamic finance presence.

\section{REFERENCES}

Abedifar, P., Molyneux, P., \& Tarazi, A. (2013). Risk in Islamic banking. Review of Finance, 17(6), 2035-2096.

Acheampong, A. O. (2019). Modelling for insight: Does financial development improve environmental quality? Energy Economics, 83(September 2019), 156179.

Akram Laldin, M., \& Furqani, H. (2013). Developing Islamic finance in the framework of maqasid al-Shari'ah: Understanding the ends (maqasid) and the means (wasa'il). International Journal of Islamic and Middle Eastern Finance and Management, 6(4), 278-289.

Al-mulali, U., Fereidouni, H. G., Lee, J. Y., \& Sab, C. N. B. C. (2013). Exploring the relationship between urbanisation, energy consumption, and $\mathrm{CO} 2$ emission in MENA countries. Renewable and Sustainable Energy Reviews, 23(July 2013), 107-112.

Al-Shalabi, A., Cottret, N., Menichetti, E., (2014). EU-GCC cooperation on energy. In: Colombo, S. (Ed.), Bridging the Gulf: EU-GCC Relations at a Crossroads. Nuova Cultura, Rome, pp. 157-222. (IAI Research Papers 1). 
Asafu-Adjaye, J., Byrne, D., \& Alvarez, M. (2016). Economic growth, fossil fuel and non-fossil consumption: A Pooled Mean Group analysis using proxies for capital. Energy Economics, 60(November 2016), 345-356.

Askari, H., Iqbal, Z., \& Mirakhor, A. (2011). New issues in Islamic finance and economics: Progress and challenges. Singapore: John Wiley \& Sons.

Azmat, S., Skully, M., \& Brown, K. (2015). Can Islamic banking ever become Islamic? Pacific-Basin Finance Journal, 34, 253-272.

Beck, T., Demirguc-Kunt, A., \& Merrouche, O. (2013). Islamic vs. conventional banking: Business model, efficiency and stability. Journal of Banking and Finance, 37(2), 443-447.

Beck, T., Demirgüç-Kunt, A., \& Merrouche, O. (2010). Islamic vs. conventional banking: Business model, efficiency and stability. Policy Research Working Paper 5446, October 2010. The World Bank, Development Research Group Finance and Private Sector Development Team.

Bernanke, B. S. (2018). The real effects of disrupted credit: Evidence from the global financial crisis. Brookings Papers on Economic Activity, 2018(2), 251-342.

Bernardini, O., \& Galli, R. (1993). Dematerialisation: Long-term trends in the intensity of use of materials and energy. Futures, 25(4), 431-448.

Bhattacharyya, S. C. (2019). Energy economics: Concepts, issues, markets and governance. London: Springer.

Bilgin, M. H., Danisman, G. O., Demir, E., \& Tarazi, A. (2021). Bank credit in uncertain times: Islamic vs. conventional banks. Finance Research Letters, 39, 101563.

Boukhatem, J., \& Moussa, F. B. (2018). The effect of Islamic banks on GDP growth: Some evidence from selected MENA countries. Borsa Istanbul Review, 18(3), 231-247.

Canh, N. P., Thanh, S. D., \& Nasir, M. A. (2020). Nexus between financial development \& energy intensity: Two sides of a coin? Journal of Environmental Management, 270, 110902.

Caporale, M.G., \& Helmi, MH, (2018). Islamic banking, credit, and economic growth: Some empirical evidence. International Journal of Finance $\mathcal{E}$ Economics, 23(4), 456-477.

Chakraborty, S. K., \& Mazzanti, M. (2020). Energy intensity and green energy innovation: Checking heterogeneous country effects in the OECD. Structural Change and Economic Dynamics, 52, 328-343.

Chen, Z., Huang, W., \& Zheng, X. (2019). The decline in energy intensity: Does financial development matter? Energy Policy, 134, 110945.

Chong, B. S., \& Liu, M. H. (2009). Islamic banking: Interest-free or interestbased? Pacific-Basin Finance Journal, 17(1), 125-144.

Cohen, S. (2020). Economic Growth and Environmental Sustainability. Columbia Climate School. Accessed August 192021 from https://news.climate.columbia. edu/2020/01/27/economic-growth-environmental-sustainability/

Dietz, T., \& Rosa, E. A. (1997). Effects of population and affluence on CO2 emissions. Proceedings of the National Academy of Sciences, 94(1), 175-179.

Du, K., \& Lin, B. (2015). Understanding the rapid growth of China's energy consumption: A comprehensive decomposition framework. Energy, 90(Part 1), 570-577. 
Durusu-Ciftci, D., Ispir, M.S., \& Yetkiner, H. (2017). Financial development and economic growth: Some theory and more evidence. Journal of Policy Modeling, 39, 290-306.

Ehrlich, P.R., \&Holdren, J.P.(1971). Impact of population growth. Science, 171(3977), 1212-1217.

El-Hawary, D., Grais, W., \& Iqbal, Z. (2007). Diversity in the regulation of Islamic Financial Institutions. Quarterly Review of Economics and Finance, 46, 778-800.

Frankel, J. A., \& Romer, D., (1999). Does trade cause growth? American Economic Review, 89(3), 379-399.

Fung, M. K. (2009). Financial development and economic growth: Convergence or divergence? Journal of International Money and Finance, 28(1), 56-67.

Furuoka, F. (2016). Natural gas consumption and economic development in China and Japan: an empirical examination of the Asian context. Renewable and Sustainable Energy Review, 56, 100-115.

Gaies, B., Kaabia, O., Ayadi, R., Guesmi, K., \& Abid, I. (2019). Financial development and energy consumption: Is the MENA region different? Energy Policy, 135, 111000.

Galli, R. (1998). The relationship between energy intensity and income levels. The Energy Journal, 19(4), 85-105.

Gheeraert, L. (2014). Does Islamic finance spur banking sector development? Journal of Economic Behavior E Organisation, 103, S4-S20.

Gillingham, K., Rapson, D., \& Wagner, G. (2016). The rebound effect and energy efficiency policy. Review of Environmental Economics and Policy, 10(1), 68-88.

Goldsmith, R. W. (1969). Financial structure and development. New Haven, CT: Yale University Press

Grassa, R., \& Gazdar, K. (2014). Financial development and economic growth in GCC countries: A comparative study between Islamic and conventional finance. International Journal of Social Economics, 41(6), 493-514.

Hanif, I. (2018). Impact of fossil fuels energy consumption, energy policies, and urban sprawl on carbon emissions in East Asia and the Pacific: A panel investigation. Energy Strategy Reviews, 21, 16-24.

Haniffa, R., \& Hudaib, M. (2010). Islamic finance: From sacred intentions to secular goals? Journal of Islamic Accounting and Business Research, 1(2), 85-91.

Hardianto, D. S., \& Wulandari, P. (2016). Islamic bank vs conventional bank: intermediation, fee based service activity and efficiency. International Journal of Islamic and Middle Eastern Finance and Management, 9(2), 296-311.

Hasan, M., \& Dridi, J. (2011). The effects of the global crisis on Islamic and conventional banks: A comparative study. Journal of International Commerce, Economics and Policy, 2(2), 163-200.

Hsing, Y. (1994). Estimation of residential demand for electricity with the crosssectionally correlated and time-wise autoregressive model. Resource and Energy Economics, 16(3), 255-263.

Hübler, M., \& Keller, A., (2010). Energy savings via FDI? Empirical evidence from developing countries. Environmental Development Economics, 15(1), 59-80.

Hunjra, A. I., Tayachi, T., Chani, M. I., Verhoeven, P., \& Mehmood, A. (2020). The moderating effect of institutional quality on the financial development and environmental quality nexus. Sustainability, 12(9), 3805. 
Hussain, H. I., Slusarczyk, B., Kamarudin, F., Thaker, H. M. T., \& SzczepańskaWoszczyna, K. (2020). An investigation of an adaptive neuro-fuzzy inference system to predict the relationship among energy intensity, globalisation, and financial development in major ASEAN economies. Energies, 13(4), 850-866.

IEA, IRENA, UNSD, World Bank \& WHO (2020). Tracking SDG 7: The Energy Progress Report. World Bank, Washington DC. (C) World Bank. License: Creative Commons Attribution-NonCommercial 3.0 IGO (CC BY-NC 3.0 IGO).

IEA. (2021). Total Final Primary Energy Consumption. Accessed November 8, 2021 from https://www.iea.org/regions/middle-east

IFC. (2020) Climate Investment Opportunities in Emerging Markets https://www. ifc.org/wps/wcm/connect/59260145-ec2e-40de-97e6-3aa78b82b3c9/3503IFC-Climate_Investment_Opportunity-Report-Dec-FIN A L. pdf?MOD=AJPERES\&CVID=1BLd6Xq

IFSB (2020). Islamic financial service industry stability report. IFSB. https://www. ifsb.org/preess_full.php?id=534\&submit=more

Imam, P., \& Kpodar, K. (2016). Islamic banking: Good for growth? Economic Modelling, 59, 387-401.

Iqbal, Z., \& Mirakhor, A. (2011). An introduction to Islamic finance: Theory and practice (Vol. 687). Singapore: John Wiley \& Sons.

IRENA. (2019). Renewable Energy Market Analysis: GCC 2019. IRENA https:// www.irena.org/publications/2019/Jan/Renewable-Energy-Market-AnalysisGCC-2019.

IRENA. (2021). Renewable Power Generation Costs in 2020. International Renewable Energy Agency, Abu Dhabi.

Izzeldin, M., Johnes, J., Ongena, S., Pappas, V., \& Tsionas, M. (2021). Efficiency convergence in Islamic and conventional banks. Journal of International Financial Markets, Institutions and Money, 70, 101279.

Jian, J., Fan, X., He, P., Xiong, H., \& Shen, H. (2019). The effects of energy consumption, economic growth and financial development on CO2 emissions in China: A VECM approach. Sustainability, 11(18), 4850.

Kassim, S. (2016). Islamic finance and economic growth: The Malaysian experience. Global Finance Journal, 30, 66-76.

Kenourgios, D., Naifar, N., \& Dimitriou, D. (2016). Islamic financial markets and global crises: Contagion or decoupling? Economic Modelling, 57, 36-46.

Khan, T. (1995). Demand for and supply of mark-up and PLS funds in Islamic banking: some alternative explanations. Islamic Economic Studies, 3(1), 1-46.

Khan, T., \& Badjie, F. (2020). Islamic Blended Finance for Circular Economy Impactful SMEs to Achieve SDGs. The Singapore Economic Review, 1-26. https:// doi.org/10.1142/S0217590820420060.

Khan, A., Chenggang, Y., Hussain, J., \& Kui, Z. (2021). Impact of technological innovation, financial development and foreign direct investment on renewable energy, non-renewable energy and the environment in belt \& road initiative countries. Renewable Energy, 171, 479-491.

King, R. G., \& Levine, R. (1993). Finance, entrepreneurship, and growth. Journal of Monetary Economics, 32(3), 513-542.

Knight, F. (1952). Economic organization. New York: Harper and Row.

Kumru, C. S., \& Sarntisart, S. (2016). Banking for those unwilling to bank: Implications of Islamic banking systems. Economic Modelling, 54, 1-12. 
Lescaroux, F. (2011). Dynamics of final sectoral energy demand and aggregate energy intensity. Energy Policy, 39(1), 66-82.

Levine, R., \& Zervos, S. (1998). Stock markets, banks, and economic growth. The American Economic Review, 88(3), 537-558.

Liu, G., (2004). Estimating energy demand elasticities for OECD countries: A dynamic panel data approach. Discussion Papers No.373, March 2004, Statistics Norway. Research Department.

Liu, Y., \& Hao, Y. (2018). The dynamic links between CO2 emissions, energy consumption and economic development in the countries along "the Belt and Road". Science of the Total Environment, 645, 674-683.

Mahi, M., Phoong, S. W., Ismail, I., \& Isa, C. R. (2020). Energy-finance-growth nexus in ASEAN-5 countries: An ARDL bounds test approach. Sustainability, 12(1), 5-20.

Medlock, K. B., \& Soligo, R. (2001). Economic development and end-use energy demand. International Association Energy Economics, 22(2), 77-105.

Mensi, W., Hammoudeh, S., Tiwari, A. K., \& Al-Yahyaee, K. H. (2020). Impact of Islamic banking development and major macroeconomic variables on economic growth for Islamic countries: Evidence from panel smooth transition models. Economic Systems, 44(1), 100739.

Meslier, C., Risfandy, T., \& Tarazi, A. (2020). Islamic banks' equity financing, Shariah supervisory board, and banking environments. Pacific-Basin Finance Journal, 62, 101354.

Mobarek, A., \& Kalonov, A. (2014). Comparative performance analysis between conventional and Islamic banks: Empirical evidence from OIC countries. Applied Economics, 46(3), 253-270.

Mulder, P. (2015). International specialization, structural change and the evolution of manufacturing energy intensity in OECD countries. The Energy Journal, 36(3), 111-136.

Mulder, P., \& de Groot, H. L. F. (2012). Structural change and convergence of energy intensity across OECD countries, 1970-2005. Energy Economics, 34(6), 1910-1921.

Namahoro, J. P., Wu, Q., Zhou, N., \& Xue, S. (2021). Impact of energy intensity, renewable energy, and economic growth on $\mathrm{CO} 2$ emissions: Evidence from Africa across regions and income levels. Renewable and Sustainable Energy Reviews, 147, 111233.

Nasreen, S., \& Anwar, S., (2014). Causal relationship between trade openness, economic growth and energy consumption: A panel data analysis of Asian countries. Energy Policy, 69, 82-91.

Nie, H., \& Kemp, R. (2013). Why did energy intensity fluctuate during 2000-2009? A combination of index decomposition analysis and structural decomposition analysis. Energy for Sustainable Development, 17(5), 482-488

Ozturk, I. (2010). A literature survey on energy-growth nexus. Energy Policy, 38(1), 340-349.

Pan, X., Uddin, M.K., Han, C., \& Pan, X., (2019). Dynamics of financial development, trade openness, technological innovation and energy intensity: Evidence from Bangladesh. Energy, 171, 456-464. 
Pham, N. M., Huynh, T. L. D., \& Nasir, M. A. (2020). Environmental consequences of population, affluence and technological progress for European countries: A Malthusian view. Journal of Environmental Management, 260, 110143.

Polzin, F., Egli, F., Steffen, B., \& Schmidt, T. S. (2019). How do policies mobilise private finance for renewable energy? - A systematic review with an investor perspective. Applied Energy, 236, 1249-1268.

Rjoub, H., Odugbesan, J. A., Adebayo, T. S., \& Wong, W. K. (2021). Sustainability of the moderating role of financial development in the determinants of environmental degradation: Evidence from Turkey. Sustainability, 13(4), 18441861.

Rafiq, S., Salim, R., \& Nielsen, I. (2016). Urbanization, openness, emissions, and energy intensity: A study of increasingly urbanized emerging economies. Energy Economics, 56, 20-28.

Rizvi, S. A. R., Arshad, S., \& Alam, N. (2015). Crises and contagion in Asia PacificIslamic v/s conventional markets. Pacific-Basin Finance Journal, 34, 315-326.

Robinson, J. (1952). The generalisation of the general theory, in the rate of interest and other essays. London: Macmillan.

Sadorsky, P. (2010). The impact of financial development on energy consumption in emerging economies. Energy Policy, 38(5), 2528-2535.

Sadorsky, P. (2011). Financial development and energy consumption in Central and Eastern European frontier economies. Energy Policy, 39(2), 999-1006.

Sadorsky, P. (2013). Do urbanization and industrialization affect energy intensity in developing countries? Energy Economics, 37(May 2013), 52-59.

Sarwar, S., Chen, W., \& Waheed, R. (2017). Electricity consumption, oil price, and economic growth: Global perspective. Renewable and Sustainable Energy Reviews, 76, 9-18.

Schumpeter, J. A. (1934). The theory of economic development: an inquiry into profits, capital, credit, interest, and the business cycle. Cambridge, MA: Harvard University Press.

Schumpeter, J. A. (1912), Theorie der wirtschaftlichen entwicklung (dunker and humboldt, leipzig); translated by Redvers Opie, 1934, The Theory of Economic Development. Cambridge, MA: Harvard University Press.

Šeho, M., Bacha, O. I., \& Smolo, E. (2020). The effects of interest rate on Islamic bank financing instruments: Cross-country evidence from dual-banking systems. Pacific-Basin Finance Journal, 62, 101292.

Sehrawat, M., Giri, A.K., \& Mohapatra, G. (2015). The impact of financial development, economic growth and energy consumption on environmental degradation. Management of Environmental Quality: An International Journal, 26(5), 666-682.

Sequeira, T., \& Santos, M. (2018). Education and energy intensity: Simple economic modelling and preliminary empirical results. Sustainability, 10(8), 2625-2641.

Shahbaz, M., \& Lean, H. H. (2012). Does financial development increase energy consumption? The role of industrialisation and urbanisation in Tunisia. Energy Policy, 40, 473-479.

Shahbaz, M., Hye, Q. M. A., Tiwari, A. K., \& Leitão, N. C. (2013). Economic growth, energy consumption, financial development, international trade and CO2 emissions in Indonesia. Renewable and Sustainable Energy Reviews, 25, 109-121. 
Shaw, E. S. (1973). Financial deepening in economic development. New York: Oxford University Press.

Sinton, J. E \& Dave, R. (2016). Delivering energy efficiency in the Middle East and North Africa: Achieving energy efficiency potential in the industry, services and residential sectors. Washington DC: World Bank.

Solar Energy Industries Association, (2021). Solar Investment Tax Credit. Accessed $8^{\text {th }}$ November, 2021 from https://www.seia.org/initiatives/solar-investmenttax-credit-itc.

Sorwar, G., Pappas, V., Pereira, J., \& Nurullah, M. (2016). To debt or not to debt: Are Islamic banks less risky than conventional banks? Journal of Economic Behavior E Organization, 132(Supplement), 113-126.

Squalli, J. (2007). Electricity consumption and economic growth: Bounds and causality analyses of OPEC members. Energy Economics, 29(6), 1192-1205.

Studenmund, A. H. (2014). Using econometrics: A practical guide, Sixth edition. Essex: Pearson.

Sukmana, R., \& Ibrahim, M. H. (2017). How Islamic are Islamic banks? A nonlinear assessment of Islamic rate-conventional rate relations. Economic Modelling, 64, 443-448.

Sun, J. W. (2002). The decrease in the difference of energy intensities between OECD countries from 1971 to 1998. Energy Policy, 30, 631-635.

Tabash, M.I., \& Dhankar, R.S., (2014). Islamic banking and economic growth -A co-integration approach. Romanian Economic Journal, 53, 61-89.

Tamazian, A., Chousa, J.P., \& Vadlamannati, K.C., (2009). Does higher economic and financial development lead to environmental degradation: Evidence from BRIC countries. Energy Policy, 37(1), 246-253.

Tamazian, A., \& Rao, B.B., (2010). Do economic, financial and institutional developments matter for environmental degradation? Evidence from transitional economies. Energy Economics, 32(1), 137-145.

Taylor, P. G., d'Ortigue, O. L., Francoeur, M., \& Trudeau, N. (2010). Final energy use in IEA countries: The role of energy efficiency. Energy Policy, 38(11), 64636474.

Voigt, S., De Cian, E., Schymura, M., \& Verdolini, E., (2014). Energy intensity developments in 40 major economies: Structural change or technology improvement? Energy Economics, 41, 47-62.

Wang, Q., Zhao, M., \& Li, R. (2019). Decoupling sectoral economic output from carbon emissions on city level: A comparative study of Beijing and Shanghai, China. Journal of Cleaner Productions, 209, 126-133.

Wang, Q., \& Wang, L. (2020). Renewable energy consumption and economic growth in OECD countries: A nonlinear panel data analysis. Energy, 207, 118200.

Wang, R., Mirza, N., Vasbieva, D. G., Abbas, Q., \& Xiong, D. (2020). The nexus of carbon emissions, financial development, renewable energy consumption, and technological innovation: What should be the priorities in light of COP 21 Agreements? Journal of Environmental Management, 271, 111027.

Waugh, M. E. (2010). International trade and income differences. American Economic Review, 100(5), 2093-2124. 
Ward, H., Radebach, A., Vierhaus, I., Fügenschuh, A., \& Steckel, J. C. (2017). Reducing global CO2 emissions with the technologies we have. Resource and Energy Economics, 49, 201-217.

World Bank Group.(2020). Transformative Climate Finance: A New Approach for Climate Finance to Achieve Low-Carbon Resilient Development in Developing Countries. World Bank. Accessed August 20, 2021 from https://openknowledge.worldbank. org/bitstream/handle/10986/33917/149752.pdf?sequence=2\&isAllowed=y

Wu, J., Hou, H., \& Cheng, S., (2010). The dynamic impacts of financial institutions on economic growth: Evidence from the European Union. Journal of Macroeconomics, 32(3), 879-891.

$\mathrm{Xu}, \mathrm{Z}$. (2000). Financial development, investment, and economic growth. Economic Inquiry, 38(2), 331-344.

Yousefi, M., Abizadeh, S., \& McCormick, K. (1997). Monetary stability and interestfree banking: The case of Iran. Applied Economics, 29(7), 869-876.

Yu, E., \& Choi, J., (1985). The causal relationship between energy and GNP: An international comparison. The Journal of Energy and Development, 10(2), 249-272.

Yu, S., Liu, J., Hu, X., \& Tian, P. (2022). Does development of renewable energy reduce energy intensity? Evidence from 82 countries. Technological Forecasting and Social Change, 174(January 2022), 121254.

Zabavnik, D., \& Verbič, M. (2021). Relationship between the financial and the real economy: A bibliometric analysis. International Review of Economics $\mathcal{E}$ Finance, 75, 55-75.

Zaman, Q. U., Hassan, M. K., Akhter, W., \& Brodmann, J. (2019). Does the interest tax shield align with maqasid al Shariah in finance? Borsa Istanbul Review, 19(1), 39-48.

Zhang, Y. J. (2011). The impact of financial development on carbon emissions: An empirical analysis in China. Energy Policy, 39(4), 2197-2203. 
This page is intentionally left blank 